\title{
Rare Cystic Tumor Occluding the External Auditory Canal : Eccrine Hydrocystoma
}

\author{
Young Nam Kim, MD and Jeong Hwan Choi, MD \\ Department of Otorhinolaryngology-Head and Neck Surgery, Sanggye Paik Hospital, \\ College of Medicine, Inje University, Seoul, Korea
}

\begin{abstract}
- ABSTRACT -
Cystic tumors arising from cystic dilatation of the excretory duct of the eccrine sweat glands or eccrine hidrocystoma are extremely rare in the external auditory canal. We describe a rare case of an eccrine hidrocystoma, confined to the external auditory canal in an adult patient. The lesion was completely excised via transcanal endoscopic approach. The diagnosis of eccrine hidrocystoma was made based on pathologic findings. Eccrine hidrocystoma should be considered as possible differential diagnoses of mass lesions in the external auditory canal. (J Clinical Otolaryngol 2019;30:229-231)
\end{abstract}

KEY WORDS : Ear auricle · Ear neoplasm · Hidrocystoma $\cdot$ Endoscopy.

\section{Introduction}

Cutaneous adnexal tumors are classified by their adnexal differentiation such as sebaceous, follicular, eccrine, and apocrine tumors. Unlike solid tumor such as ceruminous adenomas ${ }^{1)}$ and ceruminous adenocarcinomas, cystic adnexal tumors are rarely reported in the external auditory canal (EAC).

Eccrine hydrocytoma (EH) was first reported in workers working in humid and warm environments in $1893 .{ }^{2)}$ EHs are more prevalent in women than in men and generally occur in ages above 50 . Central face, especially, lower lid is the most prevalent location. EHs are extremely rare in the EAC, with only a few cases reported in the English literature. ${ }^{3-5)}$

Hidrocystoma are considered a type of differentiat-

논문접수일 : 2019년 5월 23일

논문수정일 : 2019년 7월 17일

심사완료일 : 2019년 9월 16일

교신저자 : 최정환, 01757 서울 노원구 동일로 1342

인제대학교 의과대학 상계백병원 이비인후-두경부외과학교실

전화 : (02) 950-1104·전송 : (02) 935-6220

E-mail:choijh92@paik.ac.kr ed benign retention cyst.

Size and number of lesions can be affected by heat, humidity, and perspiration. ${ }^{6}$

Here, we present a rare case of an $\mathrm{EH}$, confined to the EAC in an adult female patient. The lesion was completely excised via transcanal endoscopic approach. The diagnosis of EH was made based on pathologic findings.

\section{Case Report}

A 43-year-old woman with a 4-year history of mass in the left EAC visited our outpatient department. She was otherwise healthy with no other significant medical problems. On otoendoscopic examination, she was found to have a soft, nontender, smooth, skin-colored mass about $0.5 \mathrm{~cm}$ in diameter in the anterior cartilagenous EAC (Fig. 1).

To evaluate the deep extent of the lesion, the patient underwent a Temporal bone computerized tomography scan (TB CT) with contract enhancement. TB CT demonstrates demonstrated a well-circumscribed $0.8 \times$ $0.5 \mathrm{~cm}$ soft tissue cystic mass with partial obstruction 
of the left EAC. Though the cystic wall was slightly enhanced, cystic fluid showed low attenuation on contrast enhanced TB CT (Fig. 2). There was no evidence of invasion or destruction of surrounding soft tissues or bone.

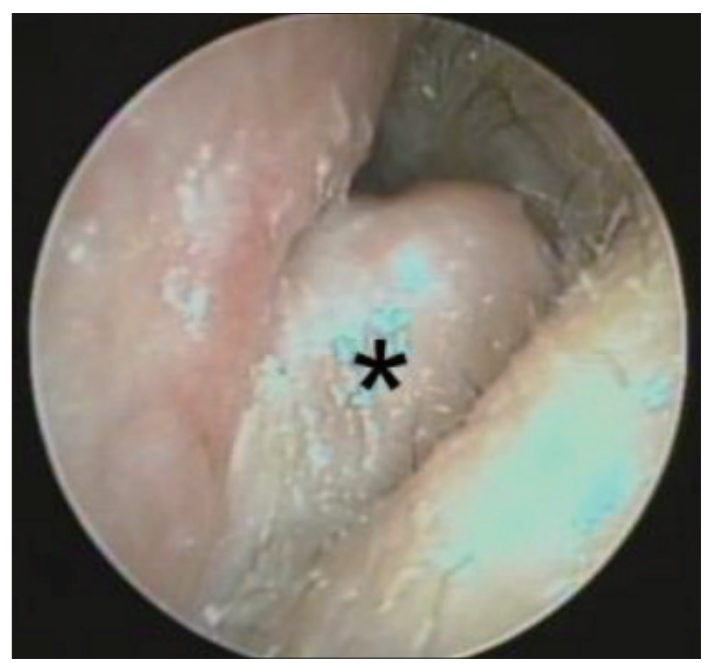

Fig. 1. Otoendoscopic examination reveals a soft, nontender, smooth skin-colored mass lesion (asterisk) blocking the external auditory canal.
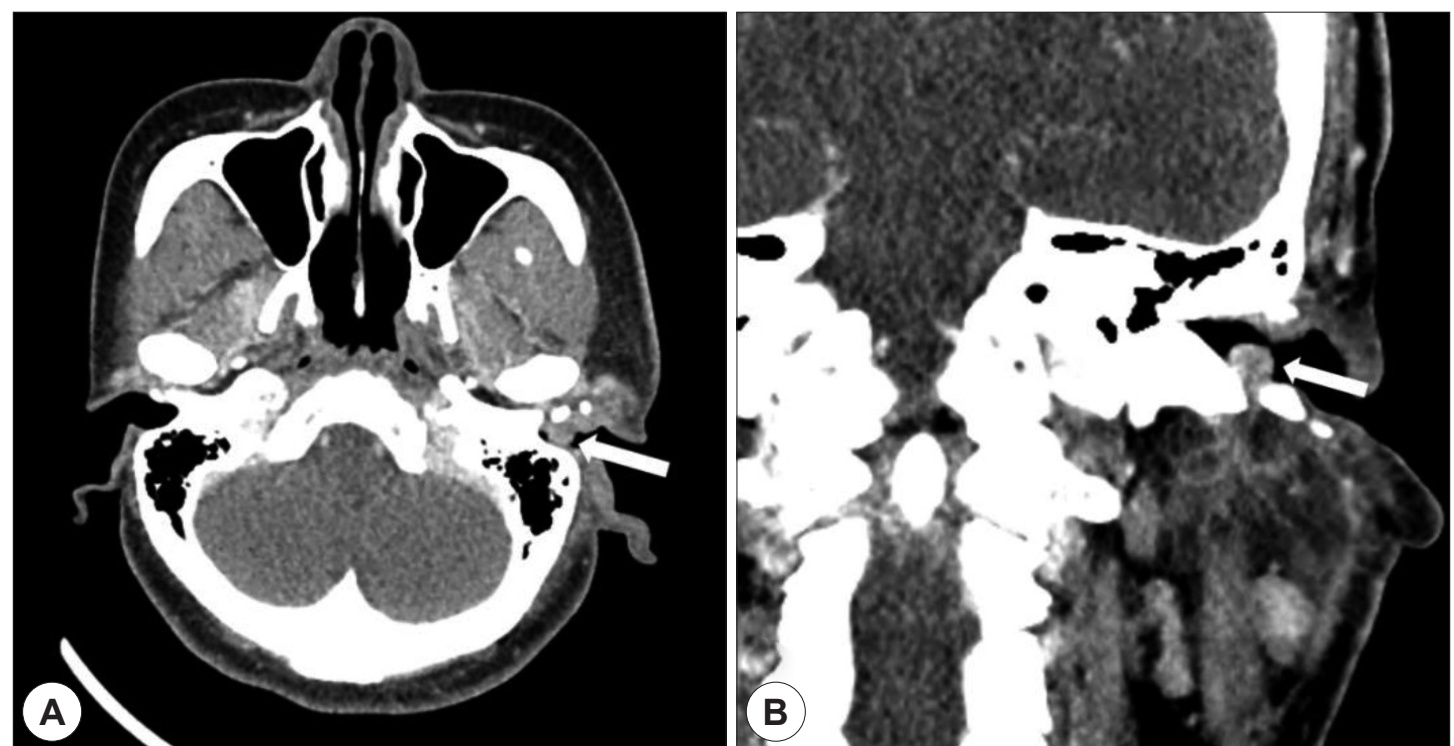

Fig. 2. High-resolution temporal bone computed tomography with contrast enhancement demonstrated a well-circumscribed $0.8 \times 0.5 \mathrm{~cm}$ soft tissue cystic mass (arrow) with partial obstruction of the left external auditory canal. Though the cystic wall was slightly enhanced, cystic fluid showed low attenuation on contrast enhanced TB CT (A, B). There was no evidence of invasion or destruction of surrounding soft tissues or bone. A : axial view. B : coronal view. 

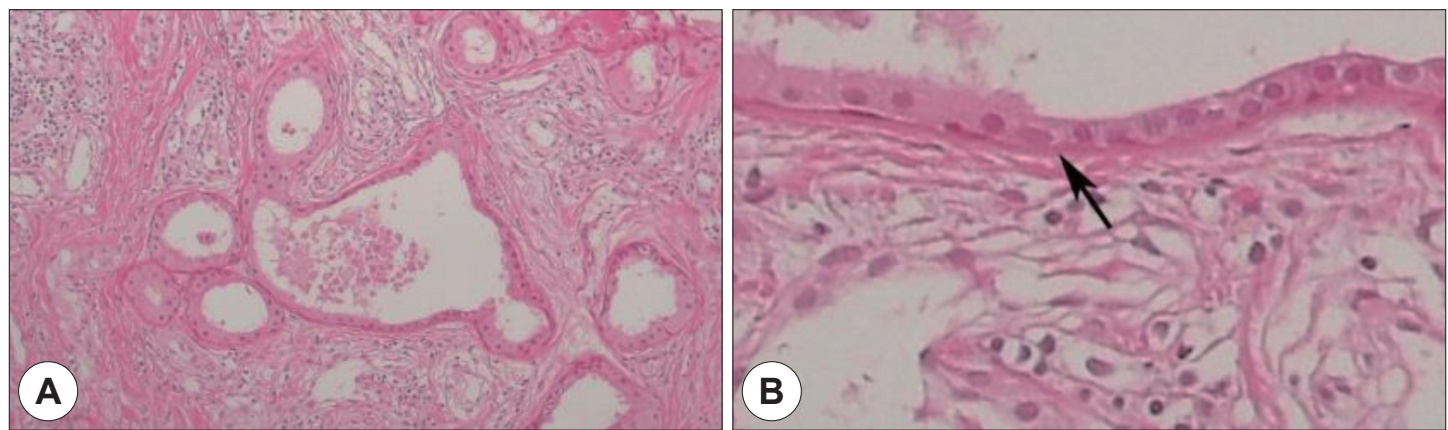

Fig. 3. Histopathological examination of the mass. Low magnification shows that the dermis contains a cystic structure with multiple sweat gland (Hematoxylin \& eosin)(A). Close-up of a cyst wall demonstrates a cuboidal epithelium (arrow), consist with an eccrine hidrocystoma (B).

the apocrine hydrocystoma, cystic and pigmented basal cell carcinoma, and cholesterol granuloma. However, they can be easily differentiated from the others by examining their histopathologic features. EH has the cysts lined with a cuboidal double-layered columnar epithelium and located in the dermis. Sweat glands are often scattered in the surroundings, as seen in histochemical PAS-negative study.

Most adnexal tumors are benign, but many have definite recurrence and malignant potential if incompletely excised. Invasive adnexal malignant tumors frequently extend radially through auricular cartilage and the fissures of Santorini into the parotid gland or into surrounding periauricular tissue. ${ }^{4)}$

The therapeutic options can be medical and/or surgical modalities. Solitary lesion can be successfully treated by surgical therapy. However, simple needle aspiration or incision and drainage can lead to recurrence. ${ }^{7)}$ Therefore, complete total excision of cystic wall is the treatment of choice. For lesions limited to the external auditory canal, without involvement of the tympanic membrane or mastoid, endoscopic transcanal approaches are becoming increasingly popular. The advantage of an endoscopic approach is superior visualization of the tumor due to the wide-angle view. In our patient, the mass was completely surgically excised with endoscopic assistance, and the patency of the EAC was maintained without any surgical complications or recurrences.

However, multiple hidrocystomas (MEH) cannot be easily removed. For alternative therapy, topical atropine, scopolamine cream, botulinum toxin injection, $\mathrm{CO} 2$ laser ablation, or oral oxybutynin have been tried. ${ }^{8.9)}$

In conclusion, although primary tumors arising from the eccrine glands of EAC are extremely rare, EH should be considered as differential diagnosis. Diagnostic imaging by enhanced CT scan is necessary for defining the characteristics, extension of the lesion and for planning the therapeutic approach. Complete excision is recommended for this lesion.

\section{REFERENCES}

1) Kim SW, Choi JH. Ceruminous Adenoma Mimicking Otofuruncle in the External Auditory Canal. Korean J Otorhinolaryngol-Head Neck Surg 2011;54(7):501-3.

2) Robinson AR. Hidrocystoma. J Cutan Genitourin Dis 1893; 11:293-303.

3) Hawke M, van Nostrand P. Eccrine hidrocystoma of the external ear canal: a case report. J Otolaryngol 1987;16(1):43-5.

4) Ioannidis DG, Drivas EI, Papadakis CE, Feritsian A, Bizakis JG, Skoulakis CE. Hidrocystoma of the external auditory canal: a case report. Cases J 2009;2(1):79.

5) Anderson PJ. Apocrine hydrocystadenoma of the ear. Otolaryngol Head Neck Surg 2005;133(6):981-2.

6) Shields JAS, Shields CL. Eyelid, Conjunctival, and orbital tumors and intraocular tumors: an atlas and textbook, 3rd ed. Philadelphia, PA: Lippincott Williams \& Wilkins;2015.

7) Comacchio F, Pedruzzi B, Tava G, Alessandrini L, Marino F, Martini A. Eccrine hidrocystoma of external ear canal. J Int Adv Otol 2012;8(2):333-8.

8) Lee MR, Ryman W. Multiple eccrine hidrocystomas. Australas J Dermatol 2004;45(3):178-80.

9) Ayhan E. A case of multiple eccrine hidrocystoma successfully treated with oral oxybutynin. Dermatol Ther 2015;28(3): 107-9 